\title{
The Significance Role of Community Engagement and Soft Power in Countering Boko Haram in Sub-Saharan Africa
}

\author{
Mustapha Kulungu a, ${ }^{*}$ \\ a ILM Foundation Institute of Los Angeles, California, United States. \\ *Corresponding author Email: drmkulungu@yahoo.com \\ DOI: https://doi.org/10.54392/ajir21410 \\ Received: 31-10-2021; Revised: 21-12-2021; Accepted: 24-12-2021; Published: 27-12-2021
}

\begin{abstract}
The Boko Haram group in the Nigerian and Lake Chad Basin has gained immense sympathy in the region, appearing to mount political challenges against corruption and social and economic inequalities. Security experts did not anticipate that the group would become violent based on its past actions. However, researchers recently have revealed that the group has had transnational connections to other terrorist groups, such as Al-Shabaab in the Horn of Africa, and Al Qaeda, which have influenced its propensity for violence. This research attempts to understand Boko Haram by examining data supplied by research, documents, and reports from numerous groups. The method implemented here entails a historical approach, including observation, a way by which the historian aims to determine the soundness of observational reports conducted by previous investigators. This research utilizes a historical methodology that requires exploring, documenting, evaluating, and interpreting past occurrences to discover indications that aid in understanding historical and present activities and to a significant but limited extent for projecting the future. This study examines the origin of Boko Haram and speculates as to its future by concentrating on why the group primarily thrives in some parts of Nigeria and the Lake Chad region. It also looks at responses to security challenges from American, Nigerian, and neighboring governments. Additionally, it looks at the use of community engagement and soft power as a possible means to mitigate violence in the region. Finally, the document identifies implications for the group's continued existence and stability in the area based on data analysis. This research also offers policy recommendations for the United States, Nigeria, and the surrounding countries that could minimize the threats of Boko Haram.
\end{abstract}

Keywords: Boko Haram, Lake Chad Basin, Terrorist group, Soft and hard power, Sub-Sahara, Community engagement

\section{Introduction}

A Nigerian-based militant group, Boko Haram, has been in the news for many years. It is a militia and militant group that utilizes guerrilla and mercenary tactics to inflict a lethal blow on its targets. This merciless group arose in 2002 under the headship of Muhammad Yusuf. The group was established in Maiduguri, located in the country's northeast. Nigeria and its neighboring countries in the Lake Chad Basin Region have witnessed many atrocities in recent years. This paramilitaries and terrorist group has openly orchestrated and claimed responsibility for various tragedies and bombings such as Abuja, the kidnapping of over 200 schoolgirls in Borno State, and many more (Parkinson \& Hinshaw, 2021; Gardner, 2011).

The terrorist group's ability amplified in 2014 and continues to this day to conduct sporadic deadly attacks on whoever they deem an enemy and collaborates primarily with the Nigerian government, Western institutions, as well as the neighboring governments in the Lake Chad Basin Region. These attacks demonstrate and emphasize the threat the terrorist and militant group poses to the United States, Western counties, and their regional interests. The resilience of Boko Haram and its lethal attacks in the region mentioned above constitutes significant security, humanitarian, and governance obstacles. Therefore, the use of Hard Power as the only approach and response will not bring peace; instead, it may be counter-productive. This article suggests using Soft Power and engaging the 
community as an alternate approach to combatting terrorism and diminishing community reliance on Boko Haram's social programs.

In the past few decades, Sub-Saharan Africa has experienced several cases of terrorism, especially in the Horn of Africa, including Somalia and Kenya, and West African countries, namely, Chad, Cameroon, and Nigeria. One of the leading terrorist groups operating in the West African region is Boko Haram, which means "Western education is forbidden." The group propagates its ideologies through terrible acts of violence, ruthless behavior, and lethal means to achieve its goals and objectives. Its activities have led to a security dilemma in Nigeria, which has meant the displacement and death of many people. Therefore, there is a need to devise viable approaches to address the Boko Haram dilemma in Nigeria.

\section{Research Methodology}

This research utilizes historical research and qualitative analysis as its methodology. The historical research assists in offering verifications and explanations in the area of human activity, seeking to uncover the various social, political, and theological phenomena that might have sanctioned the rise of Boko Haram, which dates back more than a decade. Historical research documents occurrences that led to the emergence of Boko Haram (Flippin, 1923:49-54). On a similar note, the research will answer many questions specially those related to solutions for combatting the terrorism menace in the region. Notably, there will be a need to record the government's achievements and failures in tackling extremism.

Historical research allows admission of data that cannot be collected through other means. It also aids in studying past events and pieces of evidence. Another key strength is that using historical research is crucial in analyzing trends presented by Boko Haram in Nigeria (Flippin, 1923:49-54). This type of study may be subject to questions of internal validity and biases in interpretation. Historical research, however, lacks control over the external variables. The primary reason for choosing this method is to understand the human culture based on Boko Haram ideologies in mainstream society.

Most importantly, historical research was critical in providing an account of the aspirations and successes of Boko Haram in the realization of its objectives. Historical analysis, aiming to predict future activities, was based on extrapolating data from the past. Another reason for choosing historical research is as a tool to explore, document, evaluate, and interpret occurrences of the past, aiming to discover indications that assist in understanding the history, the present, and prediction of the future, and searching for solutions to the violence (Tan, 2015:1-5). The practical argument of historical research is to help us understand the choices available to us, thus providing a vital standpoint for understanding and resolving present and future challenges.

\section{A Brief Description of Boko Haram}

Boko Haram is a West African militant group whose principal reason is institutionalizing Sharia or Islamic Law in the region. Boko Haram operates from vulnerable geographical areas in Nigeria, Kaduna, Borno, Bauchi, Kana, and Yobe (Okereke, 2014). The origin of Boko Haram is traced back to the 1990s when the group commenced organizing itself under the cleric Mohammed Yusuf. In 2003, the group conducted its first attack on police stations in Yobe state, followed by a full-fledged uprising in 2003 (Porra et al. 2014). Finally, in 2009, it spread into various northern areas of Yobe, Kano, and Borno. It is worth noting that the actions of Boko Haram were nonviolent during its formation but evolved gradually to implement violent attacks.

On May 19, 2021, Abu Musab al-Barnawi, the Islamic State West African Province (ISWAP) rival militant group to Abukar Shekau, announced that Shekau was dead on May 18, 2021, by detonating an explosive device for fear of being captured by ISWAP. With many other reliable sources, the Nigerian intelligence has also confirmed it. Also, many of the Boko Haram guerrilla fighters have pledged legion to Abu Musa al-Barnawi as their new leader. AlBarnawi, a son to the founding father of Boko Haram, has been lately consolidating his power over the Chad Basin. He is the de facto new face of Boko Haram (Kurtzer, 2021). 


\section{Theological Underpinnings}

Boko Haram's theological underpinnings are solely founded on jihadism principles and the propagation of a Salafi perspective relative to Islamic law in general and, more so, its penal code. Such principles ensure strict adherence to Wahhabism, an ideology that perceives other Islamic forms as idolatrous. On several occasions, the group has referred to itself as Jama'atu Ahlis Sunna Lidda'awati Wal-Jihad, which implies individuals who endeavor to propagate the teachings of the prophet and practice jihad, despite its violent leadings (Stewart et al., 2002). Boko Haram's central aim is to establish the Islamic State in Nigeria and further opposes the continuity of Western education and values. Boko Haram has continually caused the state of unrest in several states in Nigeria (Akpan et al., 2014). In the most recent attacks, the group targeted Christians and their churches to cleanse the Nigerian states of outlier ideologies and end satanic practices. In essence, Boko Haram is designed to continue jihadism.

Boko Haram has continually expanded and executed assaults, despite the government's efforts to contain its activities and growth. It is reported that the group has killed over 20,000 people since its inception; hence, being ranked as one of the deadliest groups in the world after ISIS (Adeoti \& Adeyeri 2012:36-41). Several factors underpin the intense nature and resilience of Boko Haram, including financial, operational, and intellectual support, the inadequacy of a legal framework nationally, and political and economic instability.

During the formation of Boko Haram and currently, the pattern was to recruit youths from various social sectors, such as artisans, madrasas, and school dropouts, in efforts to create a fighter class (Agbiboa \& Maiangwa 2014a:63-97). Ultimately, the group became highly radicalized under Abubakar Shekau through weapons and explosives training programs, aided by other radical groups, including Al Qaeda in the Islamic Maghreb and Al Shabaab (Toland \& Yoong, 2011). This support enabled the group to gain momentum and begin advancing its Salafist agendas in the region. At present, Boko Haram continues to have access to funding accumulated from various sources, especially daily remittances from the loyalists that Yusuf had empowered with capital for commercial startups in motorcycles, shoe shining, and other small businesses. In addition, several organizations that are registered as charities outside Nigeria have been identified as sources of financial support.

The group has relied continuously on social elites to support and recruit youths into terror. Initially, Boko Haram relied on gullible individuals for its operation. However, its current operation transcends the use of misguided and innocent teens to the use of intellectuals, such as lecturers (Agbiboa 2013a). For instance, Dr. Mohammed Yunus, a Kogi State University lecturer, was recently charged with participation in the radicalization and recruitment of youths into the Nigerian-based terrorist group (Adeoti \& Adeyeri 2012:36-41). Additionally, fighters from other regions have joined the resultant militancy, thus providing experienced fighters and access to weaponry from various places.

Boko Haram has benefited from the lack of adequate legal tools to address terrorism. That is one of the main factors contributing to the group's resilience. The inadequate legal framework has led to the dismissal of terrorism charges for people linked to terrorism in the region. However, in 2011, the Nigerian government enacted a robust TPA (Terrorism Prevention Act) to address the gaps. To advance the inter-agency counterterrorism undertaking, the Terrorism Prevention Act (TPA) confers coordinating agencies with more authority and defines the precise counterterrorism roles of responsible bodies. Also, the Act authorizes police to arrest and prosecute accused terrorists. Besides, it delineates exact procedures for magistrates to follow when deciding on the penalty for heinous crimes of terrorism.

In most cases, Boko Haram has exploited advantages that arise from the porous northern border. With one of the most substantial extended boundaries of about $4900 \mathrm{~km}$ (3047.719 miles), some areas in the north remain under-patrolled, making it easy for the militant group to carry out its activities (Smith, 2015). Also, there has been a lack of military cooperation between Nigeria and Cameroon, subsequently facilitating crossovers between the nations. Thus, eliminating Boko Haram units from the two countries depends on military collaboration.

\section{Contributing Factors to the Rise of Boko Haram and Its Lethal Nature}

Many factors underpin the rise of Boko Haram in Northern Nigeria. Some of these factors are attributable to economic and social challenges, ethnic and religious strife, and political tensions. Complicit economic and social factors cause high unemployment rates and poverty in the region. Security studies in the West African area have 
revealed that people deprived of economic opportunities resort to terrorist activities to express their grievances (Iyi \& Strydrom 2018). According to Borno State Governor Kashim Shettima, poverty is a primary reason that drags at the Northern Nigerian community. Unemployment drives youths to join radical groups to provide sustenance, thereby enhancing the terrorist group's workforce. Despite efforts by the Nigerian military to reduce Boko Haram militants, youths have continually joined terrorist groups at an alarming rate (Grote \& Roder 2012). Further, cooperation with the communities is one of the main reasons the groups are more lethal than any other group. Several studies have reported that large salaries enable recruitment-adult women in Borno State stockpile arms for the group in their huts (Walker, 2016).

According to Mark Wilson (2018) of BBC Monitoring, the new media has tracked local, regional, and global media outlets reporting on Boko Haram ambushes in 2016 and 2017. Figure 1 shows that Fatalities increased, and its targets stayed the same. This magnitude of fatalities increase is shown in figure 1 . In 2016, at a minimum, 910 casualties were recorded, and in 2017, Boko Haram killed 967 people, a significant increase in death.

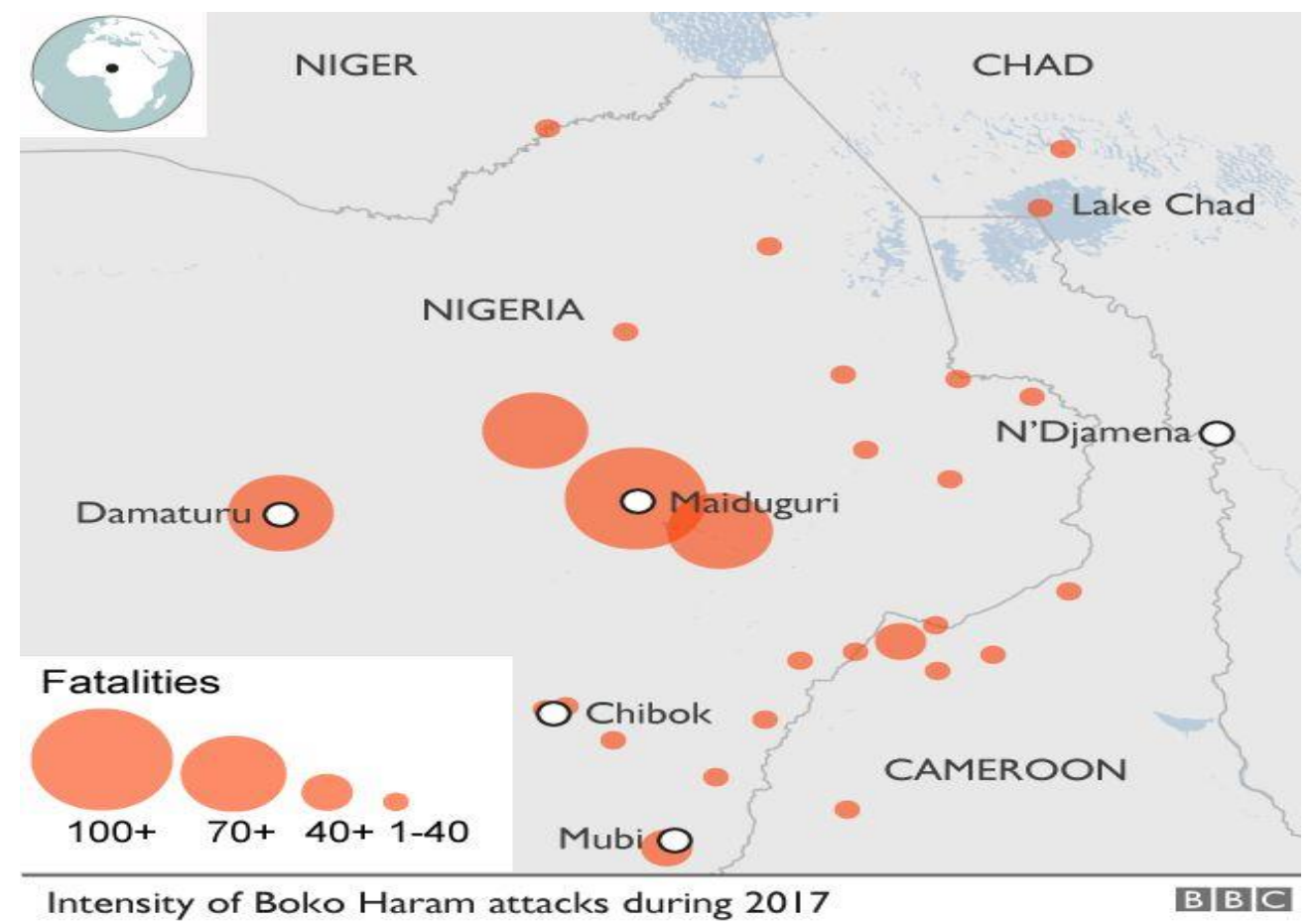

Figure 1. Attack of Boko Haram during 2017

Basically, between 2016 and 2017, the group has heavily targeted the most concentrated and populated area as the soft target in Maiduguri, Damaturi, and Mubi, Borno state, the bordering countries of Lake Chad Basin. The militant group targeted people in mosques, villages, and militaries. In addition, due to the ongoing insurgency in the region, many people in villages of bordering countries lost their livelihood and were displaced from their homes, fleeing the violence.

According to the Armed Conflict Location \& Event Data (ACLED), 2020 report, the Lake Chad Basin region has suffered the most fatalities. From January 2009 to 2020, approximately 59000 people have lost their lives, making it the most lethal area in the Sub-Saharan region. From the beginning of 2009 to 2020, the Armed Conflict Location \& Event (ACLED) recorded various incidents, in which individuals were murdered (Figure 2). The totals include the deaths of suspected Boko Haram fighters, Nigerian Armed Forces, mercenaries, and civilians.

Other factors that lead to increased Boko Haram activities are religious and ethnic. Religious fundamentalism, of course, likely plays the primary role in the propagation of Boko Haram activities (Aghiboa 2014:400-417). The group conducts its heinous crimes based on extreme religious ideology. In most cases, the group carries out its activities based on Islamic fundamentalism. The group uses extremist and fundamentalist interpretations to justify its actions. Ethno-religious conflicts are also part of the equation. Nigeria is said to have experienced ethnic as well as religious conflicts. 
Political factors, also, are shown to contribute to terrorist activities, becoming some of the root causes that lead to terrorism. According to Andrew Walker (2016), civil wars, high repression levels, weak government and political institutions, lack of political stability, corruption, and lack of civil liberties are the main non-religious forces underlie terrorism in the region (Walker, 2016). Also, several studies conducted in the northern parts of Nigeria have blamed the emergence of the terrorist group on weakness and corruption among political elites. Therefore, it is believed that Boko Haram is a political construct championed by the region's political elites.

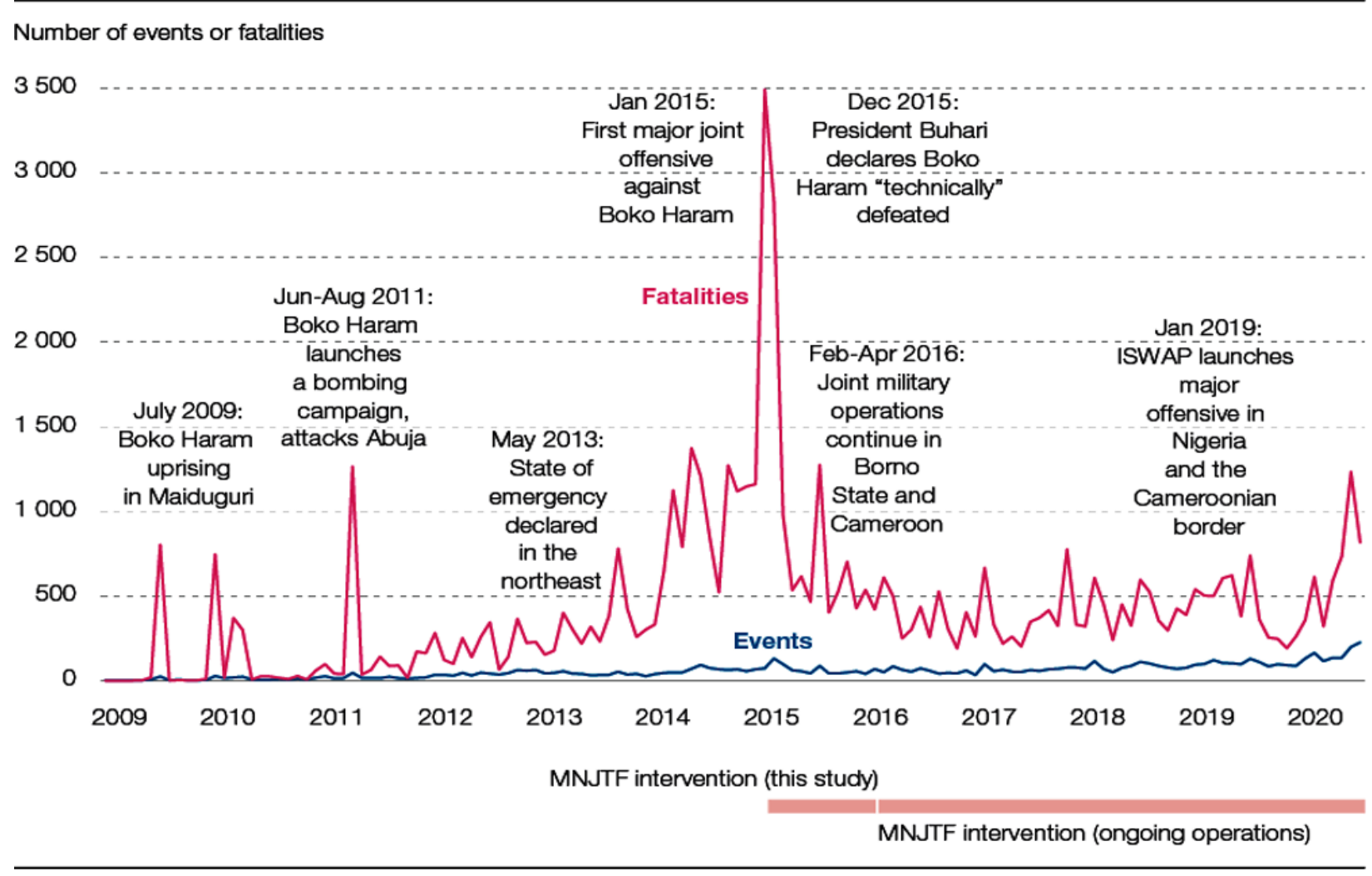

Figure 2. Events and fatalities in the Lake Chad region, 2009-20

Note: Data available through 30 June 2020.

Source: Authors, based on data from ACLED (2020), The Armed Conflict Location \& Event Data Project.

\section{Political and Economic Instability Contribute to Boko Haram Strength}

As already mentioned, economic and political factors are the key drivers that sanction the continued activities of Boko Haram in Nigeria. Based on economical factors, Nigeria's economy is highly dependent on oil, yet there has been a significant decline in oil prices. A few political elites' control most of the country's oil reserves, inevitably fueling extensive corruption, leading to a delegitimized political system and economic inequality (Ajayi, 1990). The country underwent an economic recession in 2016-2017, which means that it is just beginning to recover from the crisis (Akwagyiram \& Ohuocha 2018). There is a limited distribution of Nigeria's wealth, which leads to inequality, lack of access to essential services, increased poverty levels, and political grievances, which have shaped continued radical movement. Besides, there are immense economic disparities between the North and other parts of the country. Northern entities allege that the South holds vital financial resources while the north remains poor. The government has also suffered from infrastructure deficits in terms of rail networks, roads, and power, which lead to low agricultural production, and food insecurity.

Ethnic divisions uniquely mark a north-south political divide. Politicians continually exploit Nigeria's religious and ethnic diversity during elections. For example, there was a dramatic split between Christians and Muslims in 2011 when Muhammadu Buhari of the Muslim North and Goodluck Jonathan of the Christian South competed for president's office. Power plays took center stage during the 2019 general elections (Ager et al., 2015). The corrupt political class has been the primary cause of violence and conflict in the region. 
Further, corruption in Nigeria has been continuously attributed to the Boko Haram insurgency in the north. Similarly, corruption has been cited as the leading reason for increasing poverty in Nigeria (Aghedo and Osuma, 2015:20822). Thus, extreme economic deprivation drives individuals to participate in terrorist activities to air their grievances and provide food, clothing, and shelter.

\section{Terrorist Trends in Sub-Saharan Africa}

Many or most terrorist groups in Sub-Saharan Africa exhibit common characteristics and have given similar demands on change. Fighting for economic, political, and social rights is a leading tactic, and marginalization plays a vital role. For example, many individuals in Nigeria live below the poverty level, despite Nigeria being ranked as among the wealthiest African nations (Olaniyan \& Asuelime, 2014:91-109). Other standard features are based on the legacy of colonialism, and ethnicity, and religion. Most terrorist organizations in Africa are Muslim radicals, whose main agenda is the purification of society. Other people, particularly Christians, are referred to as infidels. Similarly, ethnicity and political marginalization play a central role in the emergence of extremism (Alao et al., 2012). Boko Haram and Al-Shabaab are empirical examples that have common agendas.

The primary counterterrorism strategy has been using military intervention in the region. Specialists see reliance on the military to deter Boko Haram as a flawed strategy. Military force is an interventionist strategy that aims to destroy Boko Haram and kill individual terrorists (Agbiboa, 2013b). For instance, the killing of leaders, such as Muhammed Yusuf, reveals that military intervention is valued as a viable option for combatting terrorism. According to many scholars, however, military intervention is not a reliable path. Over the years, Boko Haram has continued to regroup and re-emerge (Cook, 2014). The use of military intervention has worsened the condition by creating chaos and room for terrorists to operate.

The government favors using collective punishment, which involves the police and the military. Scholars view unlawful detainment as a form of human rights abuse that should be avoided and collective punishment as torturous and murderous. Collective punishment, in which groups are killed once, has continuously inflicted pain on the civilian population, especially the Muslim communities (Maiangwa et al., 2012:41-57). Muslim communities are mainly targeted in the war on terror, and divisions between Christians and Muslims are exacerbated.

Understanding cultural and political social networks and establishing community engagement in these countries is essential in countering terrorism and improving relations with the Muslim community, which should be foremost, given the large population (Onuoha, 2014). Social Network Analysis designates a family of statistical methods that seek to support the investigations and the patterns of statistical analysis. Social Network Analysis (SNA) assists in identifying the people who have had contact with criminals and helps identify those who themselves exhibit suspicious patterns of behavior (Campbell, 2014). In other words, SNA works on the premise that people who have had contact with criminals spread their ideologies to others, making identification easier. Additionally, community engagement assists efforts to repudiate terrorist propaganda and extremism, provides terror-related information to security agencies, and helps identify violent extremists in the region (Musa, 2012:111-124). Some scholars recognize community engagement as crucial in mitigating risks that arise from terrorism. In Western countries, mainly the United Kingdom, community engagement has been applied to an advantage in the deterrence of violent extremism (Doukhan, 2012). However, others are opposed to applying SNA in anti-terrorism initiatives as it leads to tensions, thereby making it a conflict-laden process. Nevertheless, the use of SNA is shown to reduce the number of attacks by Boko Haram annually.

\section{Building New Paths with Soft Power and Community Engagement}

Many terrorist organizations apply violence as a means of realizing their objectives. In this regard, hard power has been used to counter extremism. Boko Haram subscribes to ideologies and beliefs that appeal to a broad audience or some people's segments within their environment (Uzodike \& Maiangwa 2012). Applying counterterrorism initiatives that embrace utilizing soft power has been hailed as successful instead of using force or military power. Although soft power has received minimal attention in combatting terrorism, there is a need to devise approaches that do not involve hard power (Udounwa, 2013). In the case of Nigeria's Boko Haram, the government has not explored the use of hard and soft power together. Soft power entails utilizing holistic approaches to focus 
on social, economic, and political causes. Community members should be taught the advantages of siding with the government as opposed to supporting Boko Haram.

Just as Kenyan government officials have found, there is a need for engaging the grassroots-soft power-to enhance community policing and devise reintegration programs. This is for Boko Haram members who have repented, thus adopting such measures as a roadmap for the more comprehensive reconciliation process (Uchehara, 2014). In this way, de-radicalization measures are set in place by addressing human needs. At some point, ex-Boko Haram members demand psychological support, especially for the child soldiers that had been abducted forcefully to participate in a war. Several scholars suggest that using amnesty laws will be vital in confronting the Boko Haram dilemma.

The Nigerian government should address the root causes of disillusionment to restore the rule of law, support democracy, and preserve national unity. The government should support all the Nigerians working for democracy and human rights (Solomon, 2012). The United States should also actively participate in countering terrorism in this part of the world. Safeguarding Nigerian borders is crucial; therefore, Nigeria should improve border patrols, mainly with Chad, Cameroon, and Niger, where frontiers are loosely guarded. This will prevent the free movement of insurgents. In addition, the government should stop the financing of terrorist activities and disrupt their logistics. Boko Haram sympathizers and other organizations finance the group (Sampson, 2016). Therefore, identifying financial sources is critical to curtailing the group's activities and access to essential supplies, such as weaponry. Reducing easy access to all kinds of dangerous and militarized weapons that may fall into the hands of the wrong people should also be employed (Rogers, 2012:1-5).

There are many challenges to restoring peace and security in the region. One of the main ways of restoring peace in Northern Nigeria is through advocating specific initiatives that are calculated to speak to the agendas of Boko Haram, the Nigerian government, and neighboring states. Several notable personnel, including former president Olusegun Obasanjo, have called for peace talks (Oyewole, 2013:253-262). However, despite the efforts to restore order through talks, Boko Haram leaders seem reluctant to yield to the dialogue. Also, efforts at reconciliation or reintegration have failed on several occasions since some people want the perpetrators to face punishment for their offenses (Osumah, 2013). Further, some Boko Haram members perceive such dialogue as merely a government ploy to undermine their agenda. At the same time, justice is hindered due to delays. However, leaders might be persuaded to allow peace if their plan has official recognition (Oyeniyi, 2014).

One of the approaches used in peacebuilding efforts is Operation Safe Corridor, a defectors program for "repentant" low-risk male combatants and a rehabilitation program for "low-risk" women. The program is considered an essential tool in the de-radicalization curriculum. The program is to smooth their return to a healthy life. As of January 2017, over one hundred ex-Boko Haram militants cleared suspected terrorists successfully have undergone through the rehabilitation program under Operation Safe Corridor. Those individuals have been rehabilitated, deradicalized, and sent back to their respective states. These individuals have been reunited with their families in Borno, Kaduna, and Kogi states, to name just a few (Onuoha, 2010:54-67). The program is only applied to individuals who surrender willingly and accept reintegration. Despite all the approaches, de-radicalization remains a viable strategy in minimizing the Boko Haram threat in Nigeria and the neighboring states. Unfortunately, peace talk initiatives continue to be avenues that may not bear fruit.

The restoration of long-lasting peace is solely dependent on peace initiatives, which the Nigerian government should employ to engage the members of Boko Haram insurgents. Military response is not a feasible solution to restoring long-lasting peace that can confront the challenges that bedevil many communities in the region. Exploring dialogue and negotiation efforts are some practical options the government should consider (Onuoha, 2012). Although previous attempts at dialogue between the government and Boko Haram have failed, there is a need to explore more options for a peaceful resolution to end decades of violence and bloodshed. Former President Olusegun Obasanjo and Mohammed Yusuf's brother-in-law, Babakura Fugu, spearheaded the first attempt toward dialogue (Ogbonnaya et al., 2014). Nevertheless, the talk was jeopardized following the assassination of Fugu. However, on several occasions, both parties have expressed interest in having a conversation to end the violence.

In 2012, Boko Haram was said to have accepted the talks. The head of the Supreme Council for Sharia in Nigeria, President Sheikh Ahmed, was to act as Boko Haram's intermediary (Okpaga et al., 2012). However, the 
negotiation failed when Sheikh Ahmed withdrew, claiming that the government was indiscreet. After several abductions and their release by Boko Haram, there have been possibilities of having renewed hopes of dialogue since the terrorist group seems fractured. Several scholars have asserted that Boko Haram is not a monolithic organization. Still, there are possibilities for winning over some of their members if other, more targeted peace options are used.

Combatting Boko Haram demands combined efforts from the U.S., Nigeria, and neighboring countries. The U.S. should continually provide its mission assistance through U.S. AFRICOM to degrade and contain Boko Haram and build partner capacity to support the course. U.S. AFRICOM's central aim is to provide equipment, training, intelligence, and advisors to promote the region (Nwankpa, 2014). In addition, the area would benefit from U.S. supplies of more intelligence support to the Nigerian forces to assist in increasing the use of nonlethal means in their fight. The U.S. can focus on providing intelligence information and the provision of electronic warfare. Improving cybersecurity is crucial for combating cybercrimes (Dowd and Raleigh, 2013).

Borrowing from the U.S. cybersecurity initiatives, the Nigerian government can proactively launch attacks on Boko Haram without being reactive in changing its tactics. Although the Nigerian Armed Forces have an immense capacity to defeat terrorist groups in the region, incorporating nonlethal and aviation effects is crucial to dismantling Boko Haram completely (Blanchard, 2014). Also, the Nigerian government should be incentivized to assist in negotiation and reconciliation efforts with the former insurgents. Notably, central efforts should focus on reintegration, demobilization, and disarmament to neutralize the expansion and growth of Boko Haram (Azumah, 2015).

\section{Limitation of the Study}

The importance of this research is to add to the emerging literature on conflicts in Nigeria in particular and in the Lake Chad Basin as a whole. It also underlines what actions the Nigerian government and its neighboring countries have used in an attempt to resolve conflicts and counter-insurgency in the region. Outcomes from this qualitative historical analysis research provided new ways of grasping the real threats and activities presented by Boko Haram to regional security. This study empowers the collective security institutions primarily in the impacted region of Lake Chad Basin, North, and Horn of Africa. To some extent, the global community recognizes the magnitude of which Boko Haram activities threaten the region's security, economy, and development stability.

This research's primary aim was to explore and understand to what degree the Boko Haram militant group has impacted the security and livelihood of people living in the neighboring countries of Nigeria's northeastern region. The main limitation of this study rests on the inability to conduct direct interviews on the ground with the people affected by the violence of Boko Haram and talk to the group's former and active members to ascertain their lived experiences. Instead, it explores and promotes the use of community engagement and soft power as a conceivable way to alleviate violence in the region. In addition, this study recognized that much of the bearing effect in the area had been distribution inequalities, economic and human suffering, and these proportions of man-made crises are beyond the scope of this study.

\section{Policy Recommendation}

1. Addressing terrorism and extremism in Nigeria demands that the government and concerned actors improve their understanding of the people. In this regard, the government should seek to address generational issues, understand their evolution over the years, and address social challenges and economic divides between rural and urban regions.

2. Identifying individuals' aspirations and their needs will assist the government in comprehending people's grievances in the region. One of the ways is to work closely with citizens and organize opinion surveys to understand better situations at the local level (Awojobi, 2015:144-50).

3. The government's development agendas should be centered on socio-economic initiatives through which it considers the local and regional demographics and on understanding local and regional cultural and political dynamics. 
4. The government should seek to repair the social fabric and cross-border communities to enhance economic ties in the region. Also, the development organization should determine robust industrial sectors such as informal sectors and seek to improve them, thereby providing employment opportunities to unemployed youths in the region (Asfura-Heim and McQuaid, 2015).

5. The U.S. plays an essential role in this Boko Haram counter-strategy, increasing its foreign military sales (FMS). Also, it can empower reintegration efforts, demobilization, incentivize disarmament, promote security force assistance, and incorporate aviation training and non-lethal effect (Oro, 2013:1-8).

\section{Conclusion and Recommendations}

Boko Haram has thrived over the years because of financial and intellectual support; adaptive and calculated attacks have made it resilient. Several factors explain the group's emergence as one of the world's most lethal terrorist groupings. For decades, the group has taken advantage of economic and political instability in the country. Noticeably, the central characteristics of the terrorist group and trends in Sub-Saharan Africa revolve around political, economic, religious, and ethnic marginalization.

Deplorably, Boko Haram has skillfully and seemingly exploited and mastered using religion as an umbrella for grievances to the point people have come to believe that religion breeds violence. Thus, it is yoked with terrorism. Nevertheless, the practical analyst of the underlying problems and the research findings conclude that religion is, substantially, the bread and butter and pretext that fuels people's emotion and builds up frustration in Nigerian society and primarily in the most affected area. In addition, the findings of this study concluded that there is a practical course of action for undertaking the threats posed by the Boko Haram militant group. This consists of addressing inequities in resources distributions, creating job opportunities for youth, fortification and adequate border protection and surveillance, and security or military teamwork among the neighboring states of the Lake Chad Basin and the help of the U.S. and developed countries.

The militant group insurgency in Nigeria and the Lake Chad Basin constitutes the most significant security risk to people's overall well-being, lives, and assets in the bordering villages, towns, and states. Accordingly, it destroys the livelihood, social growth, and mobility of those most affected and their countries in general. It also displaced them from their homes, making them refugees in their homeland and seeking shelter in the neighboring countries. The Nigerian government, primarily and those of the Lake Chad Basin region with their logistical support and a joint multinational task force for decades, have not been entirely successful in containing and defeating the Boko Haram insurgency using military force.

Military intervention is used precisely, strategically, and proportionally to eliminate the imminent danger to human lives, properties, and government interest in the short run. It is not to be used as a long-term approach to address terrorism activities. The Nigerian and Lake Chad Basin governments must strive to understand the contributing factors behind Boko Haram insurgency activities and address their grievances accordingly.

To adequately tackle the Boko Haram insurgency in the region, all participating members of the Multinational Joint Task Force (MNJFT) must rethink their existing approach and acknowledge that using military force alone is ineffective and counterproductive to eradicate terrorism in West Africa and the Lake Chad Basin. The military force causes a lot of collateral damage and properties loss. Accordingly, it angers the public that innocent residents are killed as casualties when the military bombs the area. In addition, the militant group will skillfully use it to campaign against the government and gain sympathy from the residents.

Nigerian people and the citizens of the Lake Chad Basin region are tired and overwhelmed by the Boko Haram killings, kidnapping, destroying livestock and properties. The governments of MNJTF in the Lake Chad Basin in particular and the Sub-Saharan, in general, are far from eradicating the fundamental systemic challenges that precipitated the birth of Boko Haram and its affiliate. Honestly, things have only deteriorated in many places in Nigeria and neighboring countries. As a result, over two million people have been displaced in Nigerian alone, and thousands of Nigerians have fled to Cameroon, Chad, and Niger. There is a need for uncorrupt, accountable, robust, and genuine leadership to address the underlying driving forces to violence and grievances and move away from pseudo transformational leadership and self-serving interests over the national interests. 
Bringing to an end or minimizing the expansion of Boko Haram insurgency needs a multipronged strategy, such as using soft power and rethinking and reinterpreting Quran for modern challenges, and addressing the grievances and economic inequalities. Also, sharing intelligence, West African neighbors, the Lake Chad Basin must become accountable and support each other to combat Boko Haram and its affiliate in the region. This article aims to recommend a strategy that, if implemented by the Nigerian and the Lake Chad Basin governments, could facilitate eradicating the issue of terrorism in the region.

\section{References}

ACLED (2020), The Armed Conflict Location \& Event Data Project, https://acleddata.com/data-export-tool/.

Adeoti, O., \& Olusegun A., (2012), History, the historian, and his work: Issues, challenges, and prospects, International Journal of Educational Research and Technology, 3(4) 36-41.

Agbiboa, D., \& Maiangwa, B., (2014a), Nigeria united in grief; divided in response: Religious terrorism, Boko Haram, and the dynamics of state response, African Journal on Conflict Resolution, 14(1) 63-97.

Agbiboa, D.E, (2014), Boko-Haram and the global jihad: 'do not think jihad is over. Rather jihad has just begun, Australian Journal of International Affairs, 68(4) 400-417. https://doi.org/10.1080/10357718.2014.891564

Agbiboa, D.E., (2013a), The Nigerian burden: religious identity, conflict, and the current terrorism of Boko Haram, Conflict, Security \& Development, 13(1) 1-29. https://doi.org/10.1080/14678802.2013.770257

Agbiboa, D.E., (2013b), The ongoing campaign of terror in Nigeria: Boko Haram versus the state, Stability: International Journal of Security and Development, 2(3) 52, 1-18. https://doi.org/10.5334/sta.cl

Ager, A., Lembani, M., Mohammed, A., Ashir, M., Abdulwahab, A., Helen de Pinho, Delobelle, P., and Zarowsky, C., (2015), Health service resilience in Yobe state, Nigeria in the context of the Boko Haram insurgency: a systems dynamics analysis using group model building, Conflict and health, 9(30) 2-14. https://doi.org/10.1186/s13031-015-0056-3

Aghedo, I., \& Osumah, O., (2015), Insurgency in Nigeria: A comparative study of Niger Delta and Boko Haram uprisings, Journal of Asian and African Studies, 50(2) 208-222. https://doi.org/10.1177/0021909614520726

Ahokegh, A.F, (2012), Boko Haram: The 21st-century challenge in Nigeria, European Scientific Journal, 8(21) 46-55.

Ajayi, A.I, (1990), 'Boko Haram' and terrorism in Nigeria: Exploratory and explanatory notes, Religion, 55: 65.

Ajayi, A.I., (2012), Boko Haram and Terrorism in Nigeria: Exploratory and Explanatory Notes, Global Advanced Research Journal of History, Political Science and International Relations, 1(5),103-107.

Akpan, F., Okonette, E., \& Olofu-Adeoye, A., (2014), Boko Haram insurgency and the counterterrorism policy in Nigeria, Canadian Social Science, 10(2) 151.

Akwagyiram, A., \& Ohuocha, C., (2018), Bonds News. February 27. Update 2-Nigeria returns to growth in 2017 after recession https://www.reuters.com/article/nigeria-gdp/update-2-nigeria-returns-to-growth-in-2017-afterrecession-idUSL8N1QH26Y

Alao, D., Oluwasegun, C., \& Oluwafisayo, A., (2012), Boko-Haram insurgency in Nigeria: The challenges and lessons, Singaporean Journal of Business, Economics, and Management Studies, 51(1106) 1-15. https://doi.org/10.12816/0003749

Asfura-Heim, P., \& McQuaid, J., (2015), Diagnosing the Boko Haram conflict: Grievances, motivations, and institutional resilience in northeast Nigeria. No. CNA-DOP-U-009272-Final. Center for Naval Analyses Alexandria Va.

Awojobi, N., (2014), The socio-economic implications of Boko Haram insurgency in the northeast of Nigeria, International Journal of Innovation and Scientific Research, 11(1) 144-50.

Azumah, J., (2015), Boko Haram in Retrospect, Islam and Christian-Muslim Relations, 26(1) 33-52. https://doi.org/10.1080/09596410.2014.967930 
Blanchard, L, (2014), Nigeria's Boko Haram: Frequently Asked Questions, 6. https://www.researchgate.net/publication/297361534 Nigeria's boko haram Frequently asked questions

Campbell, J., \& Harwood, A., (2018), Boko Haram's Deadly Impact, August 20. https://www.cfr.org/article/bokoharams-deadly-impact

Campbell, J., (2014), U.S. policy to Counter Nigeria's Boko Haram. Council on Foreign Relations. Available July 7, 2019. From https://www.cfr.org/blog/tracking-boko-haram-nigeria-security-tracker

Cook, D., (2014), Boko Haram: A New Islamic State in Nigeria, James A. Baker III Institute for Public Policy 11.

Doukhan, D., (2012), Who Are You, Boko Haram?. International Institute for Counter-Terrorism.

Dowd, C., \& Raleigh, C., (2013), The myth of global Islamic terrorism and local conflict in Mali and the Sahel, African affairs, 112(448) 498-509. https://doi.org/10.1093/afraf/adt039

Flippin, S., (1923), The Importance of Historical Research to the Teaching of the Social Sciences, The Journal of Social Forces, 2(1) 49-53. https://doi.org/10.2307/3005179

Gardner, F., (2011), Abuja attack: Car bomb hits Nigeria U.N. building, BBC News. https://www.bbc.com/news/world-africa-14677957

Grote, R., \& Röder, T., (2012), Constitutionalism in Islamic countries: between upheaval and continuity, Oxford University Press, New York.

Iyi, J.M., \& Strydom, H., (2018), Boko Haram and international law, Springer, Cham. https://doi.org/10.1007/978-3319-74957-0

Kurtzer, J., (2021), Boko Haram's Leader Is Dead: What Are the Humanitarian and Security Implications? https://www.csis.org/analysis/boko-harams-leader-dead-what-are-humanitarian-and-security-implications

Maiangwa, B., Uzodike, U., Whetho, A., \& Onapajo, H., (2012), "Baptism by Fire": Boko Haram and the Reign of Terror in Nigeria, Africa Today, 59(2) 41-57. https://doi.org/10.2979/africatoday.59.2.41

Musa, O., (2012), Socio-economic incentives, new media, and the Boko Haram campaign of violence in Northern Nigeria, Journal of African Media Studies, 4(1) 111-124. https://doi.org/10.1386/jams.4.1.111 1

Nwankpa, M., (2014), The politics of amnesty in Nigeria: A comparative analysis of the Boko Haram and Niger Delta insurgencies, Journal of Terrorism Research, https://doi.org/10.15664/jtr.830

Ogbonnaya, U., Ogujiuba, K., \& Stiegler, N., (2014), Terrorism in Nigeria: Implications of Boko Haram's movement for security and stability in the ECOWAS sub-region, African Security Review, 23(2) 145-160. https://doi.org/10.1080/10246029.2014.903378

Okereke, N.E., (2014), The Resilience of Boko Haram: Myth or Reality?, Counter Terrorist Trends and Analysis, 6(7) 8-12.

Okpaga, A., Chijioke U., \& Okechukwu E., (2012), Activities of Boko Haram and insecurity question in Nigeria, Oman Chapter of Arabian Journal of Business and Management Review, 34(965) 1-23. https://doi.org/10.12816/0002163

Olaniyan, A., \& Asuelime, L., (2014), Boko Haram insurgency and the widening of cleavages in Nigeria, African Security, 7(2) 91-109. https://doi.org/10.1080/19392206.2014.909246

Onuoha, C., (2012), Boko Haram: Nigeria's Extremist Islamic Sect, Al Jazeera Centre for Studies, 29(2) 1-6.

Onuoha, C., (2014), A danger not to Nigeria alone: Boko Haram's transnational reach and regional responses, https://pscc.fes.de/e/a-danger-not-to-nigeria-alone-boko-harams-transnational-reach-and-regionalresponses/

Onuoha, F., (2010), The Islamist challenge: Nigeria's Boko Haram crisis explained, African Security Review, 19(2) 54-67. https://doi.org/10.1080/10246029.2010.503061 
Osumah, O., (2013), Boko Haram insurgency in northern Nigeria and the vicious cycle of internal insecurity, Small Wars \& Insurgencies, 24(3) 536-560. https://doi.org/10.1080/09592318.2013.802605

Oyeniyi, A., (2014), One voice, multiple tongues: Dialoguing with Boko Haram, Democracy and Security, 10(1) 7397. https://doi.org/10.1080/17419166.2013.858031

Oyewole, S., (2013), Boko Haram and the challenges of Nigeria's war on terror, Defense \& Security Analysis, 29(3) 253-262. https://doi.org/10.1080/14751798.2013.820968

Parkinson, J., \& Hinshaw, D., (2021), Bring Back Our Girls: The Astonishing Survival and Rescue of Nigeria's Missing Schoolgirls, Swift Press.

Porra, J., Hirschheim, R., \& Parks, M., (2014), The historical research method and information systems research, Journal of the Association for Information Systems, 15(9) 536. https://doi.org/10.17705/1jais.00373

Rogers, P., (2012), Nigeria: The generic context of the Boko Haram violence, Monthly Global Security Briefing, 1-5.

Sampson, T., (2016), The dilemmas of counter-bokoharamism: Debating state responses to Boko Haram terrorism in northern Nigeria, Security Journal, 29(2) 122-46. https://doi.org/10.1057/sj.2013.2

Smith, M., (2015), Boko Haram inside Nigeria's unholy war, I.B. Tauris, London. https://doi.org/10.5040/9780755619085

Solomon, H. (2012), Counterterrorism in Nigeria: responding to Boko Haram, The RUSI Journal, 157(4) 6-11. https://doi.org/10.1080/03071847.2012.714183

Stewart, F., Holdstock, D., \& Jarquin, J., (2002), Root causes of violent conflict in developing countries Commentary: Conflict-from causes to prevention?, BMJ, 324, 7333: 342-345. https://doi.org/10.1136/bmj.324.7333.342

Tan, J., (2015), Historical Research: A Qualitative Research Method, April 21: 1-5

Toland, J., \& Yoong, P., (2011), An Exploration of Historical Methods for Information Systems Research, In PACIS, 193.

Uchehara, E., (2014), Peace Talks Initiatives between the Boko Haram and the Nigerian Government, International Journal of Business and Social Science, 5, 6(1) 130-138.

Udounwa, S., (2013), Boko Haram: Developing New Strategies to Combat Terrorism in Nigeria, ARMY War College Carlisle Barracks, PA. https://doi.org/10.21236/ADA590264

Uzodike, O., \& Maiangwa, B., (2012), Boko Haram terrorism in Nigeria: Causal factors and central problematic, African Renaissance, 9(1) 91-118.

Walker, A., (2016), Eat the heart of the infidel': the harrowing of Nigeria and the rise of Boko Haram, Hurst \& Company, London.

Wilson, M., (2018), Nigeria's Boko Haram attacks in numbers - as lethal as ever, BBC Monitoring. https://www.bbc.com/news/world-africa-42735414

Funding: No funding was received for conducting this study.

Conflict of Interest: The Author has no conflicts of interest to declare that they are relevant to the content of this article.

\section{About The License}

(C) The Author 2021. The text of this article is open access and licensed under a Creative Commons Attribution 4.0 International License

Cite this Article

Mustapha Kulungu, The Significance Role of Community Engagement and Soft Power in Countering Boko Haram in Sub-Saharan Africa, Asian Journal of Interdisciplinary Research, 4(4) (2021) 88-99. https://doi.org/10.54392/ajir21410 